\title{
Humoral immunity in Hansen's Disease
}

\author{
Part of the Master's thesis. Department of Rheumatology/Laboratory of Rheumatology Investi- \\ gation - LIM-17, of the University Hospital of the College of Medicine of the Universidade de \\ São Paulo. Partially funded by the Foundation for the Development of Rheumatology, Brazil- \\ ian Society of Rheumatology (other funds) and Sandoz Laboratories - São Paulo, Brazil
}

For many years immune response in leprosy has been studied. Since 1960 several reports dealing with humoral immunity have been described in the literature. Different autoantibody rates occur in leprosy. There is an increase in the prevalence of autoantibodies in elderly patients with long standing disease, in lepromatous leprosy and in those with reactional states. The diferences in rates among various studies are attributed to different methods and variations among patient samples concerning age, gender, polar forms, therapy and other elements. The prevalence of numerous antibodies, immune complexes, cryoglobulins and complement levels have been studied by many authors. This also highlights the importance of the more recent reviews of anti-Mycobacterium leprae glycolipid antibodies such as the anti-phenolic glycolipid-I antibodies in which titers are variable and depend on genetic factors.

UNITERMS: Antibodies. Hansen's Disease. Immunity. Cryoglobulins. Immune complexes. Complement.

\section{INTRODUCTION}

$\mathrm{T}$ he activation of both humoral (46) and cellular (71) immunity has been detected in Hansen's Disease $(17,18)$. Especially in the lepromatous form, the polyclonal activation of B-cells has been known since the 1960 's by means of antibody detection and seric hypergammaglobulinemia and is considered to be due to the chronicity of the disease. On the other hand, specific antibodies against the mycobacteria $(03,31,44)$, other

\section{Address for correspondence:} Waldenise Cossermelli Messina

Av. Dr. Arnaldo, 455 - $3^{\circ}$ andar - Reumatologia

São Paulo/SP - Brasil - CEP 01246-903 mycobacterial immunoglobulins (15) and autoantibodies have been described $(20,21,23,27,38,51,61,67)$, as in other infectious diseases $(01,10,11,26,30,37,42,43,50,60)$, and are important for analysis and diagnosis $(57,58,65)$.

\section{SPECIFIC ANTIBODIES}

In 1982, Hunter et al. (44), chemically described a glycolipid from Mycobacterium leprae cultivated in armadillos. Later the same structure was found in infected human tissues. Through enzyme-linked immunosorbent assay (ELISA), it was shown that these antibodies were specific to the M. leprae infection $(19,40)$ and that patients with tuberculosis and other mycobacterial infections did not show any reaction to this antigen. The false- positive rate was $3 \%$, and lepromatous patients presented the most 
significant rates of these antibodies called anti-phenolic glycolipid-I antibodies (anti-PGL-I) (84). Due to the low presence of levels of anti-PGL-I in patients exposed to the ELISA test for this antibody, is not cosidered diagnostic (34) but has been considered useful for epidemiological studies, especially in endemic areas $(19,75)$ and patients that have been in contact with leprosy.

Recent studies have shown that the scope and magnitude of antibodies produced by mice against certain mycobacterial proteins may vary greatly (16). In studies with M.leprae, it is believed that these different responses are influenced by genetic background. After inoculating mice with M.leprae sonicate and the recombinant $65 \mathrm{kDa}$ protein, differences in the number and structure of the recognized epitopes were noted, and the participation of non-H2 genes was demonstrated (04).

\section{AUTOANTIBODIES}

Among rabbits, bacterial immunization causes development of antigammaglobulins very similar to the rheumatoid factor (01). Late, anti-DNA antibodies may be found along with proliferative glomerulonephritis diagnosed during autopsy (25). However, in Hansen's Disease, the sole presence of these antibodies has not been related to any specific clinical manifestation, except when immune complex deposits occur. In 1966, Azevedo and Melo (06) recognized that the decrease in complement activation in reactional states of leprosy is due to the complement binding by the antigen-antibody complexes.

The autoantibodies in Hansen's Disease appear at different rates that vary according to the population studied, to the methods used and to the period in which they were carried out. Although some study groups have shown a higher prevalence of Hansen's Disease than in the control groups (62), several autoantibodies have been identified, among them anti-nuclear factors $(11,14,54,64,82)$, rheumatoid factors $(21,42,64,67,82)$, anti-tireoglobulin $(12,52,64,82)$, anti-smooth muscle, anti-cardiolipin $(28,36,39,79)$, anti-collagen I and II (53), as well as false positive syphilis reactions $(35,52)$, that may indicate the presence of anti-phospholipid antibodies and/or a crossreaction with the mycobacterial antigenic components.

The production of antibodies is more characteristic of the lepromatous form $(23,52,64)$, demonstrated by high titers of gammaglobulin $(02,03,73)$ especially in the reactional states, and can be detected also in patients in disease remission (82). An inverse relation between the antibody and the celular reactions has also been suggested (63). Long duration of disease, old age, and a history of reccurring erithema nodosum leprosum (ENL) predispose the formation of autoantibodies in these patients (63).

In several studies $(05,14,20,21,23,47,52,64,66,68)$. the detection of the rheumatoid factor ranges from zero (55) to $100 \%$ (28). Since the latex fixation test is more sensitive and less specific than the Waaler-Rose test, it can be assumed that this sensitivity could contribute to these differences in rate. In addition, in studies where the rates are very high, the number of patients studied is low (08). The identification of seric rheumatoid factor in leprosy patients occurs both in tuberculoid and lepromatous forms, although with a higher incidence in the latter (64). According to Pechclai et al.. (64), rheumatoid factor titers can be low, depending on the population chosen. In hospitalized patients titers up to 1:5120 were found (21).

The production of seric factors very similar to rheumatoid factor can be stimulated by microorganisms (rabbit hyperimmunization with Escherichia coli and Bacillus subtilis) (01). No correlation was found with arthritis or rheumatoid disease in these subjects. It is known that rheumatoid factors were also detected in infections such as tuberculosis (83) and syphilis (60).

Antinuclear factors and L.E. cells were studied in leprosy patients as an attempt to diagnose a possible association with connective tissue diseases (74), since joint and skin manifestations may mimic several rheumatic symptons. Similary to rheumatoid factor, the rates found $(08,23,47)$ varied greatly, ranging from zero $(55)$ to $29 \%$ $(14,63)$. Although L.E. cells have been found $(14,47,52)$ and leprosy patients with lupoid aspects have been reported (12) the association with systemic lupus erythematosus was not significant.

Autoantibodies reactive to native or denatured collagen type II were detected in the serum of 11 out of 20 patients with the lepromatous form in which antibody levels were significantly higher than those with rheumatoid disease; however, none of these patients had any signs of arthritis (24).

\section{CIRCULATING IMMUNE COMPLEXES $(22,69,70,85)$, CRYOGLOBULINS ${ }^{(52)}$ AND COMPLEMENT (22)}

Although the presence of autoantibodies does not always mean pathogenicity, the presence of immune complexes in the tissues does suggest some participation in clinical manifestations (86) 
The perivascular immune complexes seen in the dermis, and bound to soluble mycobacterial antigens were detected in patients with ENL, suggesting a possible role in its pathogenesis (56). Immune complexes have also been demonstrated in renal biopsies of leprosy patients (32) and related to a decrease in complement in these patients (09).

Patients with borderline leprosy in reaction showed circulating immune complexes (IgG and the $\mathrm{C} 3$ fraction), while in lepromatous leprosy immune complexes were formed by rheumatoid factor and IgM, especially in those patients with arthritis (59), anti-mycobacterial antibodies and cryoglobulins (13).

By using the $\mathrm{C} 1 \mathrm{q}$ reaction method, immune complexes were also identified in the serum of the patients with the tuberculoid form, in contrast to previous studies that showed elevated immunecomplexes only during ENL Reaction (72). Seventy percent of the patients with the lepromatous form studied by Rojas-Espinosa et al.. (72) and $76 \%$ of the patients studied by Moran et al.. (56) showed circulating immune complexes when the same method was employed.
Complement detection may be useful to the diagnosis of Hansen's Disease $(48,76,77,81)$. High levels of complement, especially of the $\mathrm{C} 2$ and $\mathrm{C} 3$ components (33) during ENL episodes have been reported (78). Titers of complement in the synovial fluid may have a practical significance when compared to blood levels (49).

Cryoglobulinemia may cause severe complications such as proliferative glomerulonephritis with linear $\mathrm{IgG}$ and IgM deposits and granular deposits of C3 (45). A high frequencys was observed during ENL, in patients undergoing treatment $(58 \%)$ and in untreated patients with ENL (52). All six patients assessed by Bonomo (13) presented mixed cryoglobulins and IgG and five have polyclonal IgM, with one IgM presenting only light-chain kappa.

Although it is generally agreed that competent immunity for bacillar destruction is mediated by an efficient T-cell response, some authors emphasize the importance of specific immunoglobulins (29) in mucosal and in patients with lesser severity of the disease (40)

Humoral abnormalities are therefore important, particularly to differential diagnosis.

\section{Resumo}

Introdução: Desde a década de 60 , tem-se observado alteraçōes da imunidade humoral na hanseniase. Os autoanticorpos apresentam-se em freqüências diversas, nestes pacientes, mais habitualmente na hanseniase virchoviana, em doença de longa evoluçāo e em surtos reacionais. Variação nas freqüências pode se atribuída a diferentes metodologias empregadas na detecçāo dos anticorpos e ao grupo de doentes selecionado. Material e Métodos: Esta revisăo enfoca os resultados obtidos em diversos estudos de auto-anticorpos, complexos imunes, crioglubulinas, complemento sérico na hanseniase. Destaca-se também, os anticorpos contra glicolipídeos do Mycobacterium leprae, como os antiglicolipídeos fenólicos I, cuja magnitude é variável e depende do patrimônio genético apresentado pelo enfermo. 


\section{REFERENCES}

1. ABE, M.; CHIMONE, S.; HIRAKO, T. - Rheumatoid factorlike substance and antistreptolysin $\mathrm{O}$ antibody in leprosy serum. Int. J. Lepr. 35: 336-344, 1967.

2. ALBERT, D.A.; WEISMAN, M.H.; KAPLAN, R. - The rheumatic manifestations of leprosy (Hansen disease). Medicine 59: 442-448, 1980 .

3. ALCOCER, J.V.; HERRERA, C.L.; GUDINO, J.; FRAGA, A. - (Abstract) Inflammatory arthropathy in leprosy. Arth Rheum. 22: 587, 1979.

4. ANDERSON, D.C.; VAN SCHOOTEN, L.U.C.A.; BARRY, M.E.; JANSON, A.A.M.; BUCHANAN, T.M.; DE VRIES, R.R.P. - A Mycobacterium leprae specific human T cell epitope cross-reactive with an HLA-DR 2 peptide. Science 1: $242-259,1988$.

5. ATKIN, S.L.; EL-GHOBAREY, A.; KAMEL, M.; OWEN, J.P.; DICK, W.C. - Clinical and laboratory studies in patients with leprosy and enthesitis. Ann. rheum. Dis. 49:715-717, 1990.

6. AZEVEDO, M.P.; MELO, P.H. - A comparative study of complementary activity of serum in polar forms of leprosy and in the leprosy reactions. Int. J. Leprol 34:34-38, 1966.

7. BERGOT, J.; NICOLI, J.; ZIEGLER, P.; DENORCHI, J. Eletrophoretic and immunoeletrophoretic study of serum proteins in leprosy. Bull. Soc. Pathol. Exot. Filiales. 55:766782, 1963.

8. BERMAN, L.O. - Exudative arthritis in leprosy. (Letter) Arth. Rheum. 20:593, 1979.

9. BJORVATH, B.; BARNETSON, F.S.; KRONVALL, G.K. Immune complexes and complement hypercatabolism in patients with leprosy. Clin. Exp. Immunol. 26:388-396, 1976.

10. BONFÁ, E. - Autoanticorpos na doença de Chagas. São Paulo. Tese (Doutorado) - Faculdade de Medicina da Universidade de São Paulo. 1991, p.24

11. BONFÁ, E.; LLOVET, R.; SCHEINBERG, M.; SOUZA, J.M.; ELKON, K.B. - Comparison between autoantibodies in malaria and leprosy with lupus. Clin. exp. Immunol. 70:529-537, 1987.

12. BONOMO, L.; DAMMACO, F.; TURSI, A.; BARBIERI, G. - Lupoid features in a case of leprosy. Int. J. Leprosy 35:65-71, 1967.

13. BONOMO, L.; DAMMACO, F. - Immune complex cryoglobulinaemia in lepromatous leprosy: a pathogenetic approach to some clinical features of leprosy. Clin. exp. Immunol. 9:175-181,1971.

14. BONOMO, L.; TURSI, A.; TRIMGLIAZZI, G.; DAMACO, F. - LE cells and antinuclear factors in leprosy. Brit. med. J. 2:689-690, 1987.

15. BOTHAMLEY, G.; SWANSON BECK, J.; AGUSNI, I.;ILIAS, M.I.; KARDJITO, T.; GRANGE, J.M.; IVANYI, J. - Antibodies to mycobacterium tuberculosis in leprosy. [Letter]. Lancet 1:1098, 1987.
16. BRETT SJ.; IVANYI, J. - Genetic influences on the immune repertoire following tuberculous infection in mice. Immunology 71:113. 1990.

17. BULLOCK, W.E. - Studies of immune mechanisms in leprosy. New Engl. J. Med 278:298, 1968.

18. BULLOCK, W.E.; HO, M.F.; CHEN, M.S. - Studies of immune mechanisms in leprosy: quantitative relationships of $\operatorname{lgG}, \lg A$ and $\operatorname{lgM}$ immunoglobulins. J. Lab. Clin. Med. 75:863-870, 1970.

19. BURGESS, P.J.; FINE, P.E.M.; PONNIGHAUS, J.M.; DRAPPER, C. - Serological tests in leprosy. The sensitivity, specificity and predictive value of ELISA tests based on phenolic glycolipid antigens, and the implications for their use in epidemiological studies. Epidem. Inf. 101:159-171, 1988.

20. CATHCART, E.S.; WILLIAMS JR, R.C - A clinical and serological study of latex fixation test in leprosy. - (Abstract) Ann. Intern. Med. 54(5):1053-1054, 1961.

21. CATHCART, E.S.; WILLIAMS JR, R.C.; ROSS, H. - The relationship of the latex fixation test to the clinical and serological manifestations of leprosy. Amer. J. Med. 31:758765,1961 .

22. CENITEAU, M.; ADAM, C.; VERROUST, P.; PASTICIER, A.; SAIMOT, G.; COULAND, J.P.; LANGUILLON, J. - Les complexes immunus et le complement dans la lèpre. Nouv, Presse Med. 10:3697-3700, 1981.

23. CHAVEZ-LEGASPI, M.; GOMEZ-VASQUES, A.; GARCIA DE LA TORRE, I. - Study of rheumatic manifestations and serological abnormalities in patients with lepromatous leprosy. J. Rheumatol. 12:738-741, 1985.

24. CHOI, E.K.; GATENBY, P.A.; MCGILL, N.W.; BATEMAN, J.F.; COLE, W.G.; YORK, J.R. - Autoantibodies to type II collagen; occurrence in rheumatoid arthritis, other arthritides, autoimmune connective tissue disease, and chronic inflammatory syndromes. Ann. rheum. Dis. 47:313-322, 1988.

25. CHRISTIAN, C.L.; DE SIMONE, A.R.; ABRUZZO, J.L Anti DNA antibodies in hyperimmunized rabbits. Arth. Rheum. 6:766, 1963.

26. COHEN, A.S. - (ed.) Laboratory diagnostic procedures in the rheumatic diseases $3^{\text {rd }}$ ed., New York, Grune \& Stratton Inc. 1985 , p. 145.

27. COSSERMELLI-MESSINA, W.; LEVY, M.; YOSHINARI, N.H.; COSSERMELLI, W. - Miosite hanseniana simulado dermatopolimiosite. Anais do XVIII Congresso Brasileiro de Reumatologia, Bahia, 1990.

28. COSSERMELLI-MESSINA, W.; BUENO, C.; GABURO JR.; N.; BARROS, P.J.L.; FESTA NETO, C.; YOSHINARI, N.H.; COSSERMELLI, W. - Detection of anticardiolipin antibodies in leprosy patients. Anais do Congresso del Cono Sur. Buenos Aires, 16 - 19 de outubro, 1991.

29. CREE, I.A.; RANCE, S.S.; BECK, J.S. - Mucosal immunity in leprosy. Int. J. Leprosy, 57:318, 1989.

30. CRUAUD, P.; YAMASHITA, J.T.; CASABONA., N.M.; PAPA, F.; DAVID, H.L. - Evaluation of anovel 2.3-diacyl- 
trehalose-2'-sulphate (SL-IV) antigen for case finding and diagnosis of leprosy and tuberculosis. Res. Microbiol. 141:679-694, 1990.

31. DAVENPORT, M.P.; McKENZIE, K.R.; BASTEN, A.; BRITTON, W.J. - The variable C-terminal region of the mycobacterium leprae 70-kilodalton heast shock protein is the target for humoral immune responses. Infection and Immunity. 60(3):1170-1177, 1992.

32. DRUTZ, D.J.; GUTMAN, R.A. - Renal manifestation of leprosy glomerulonephritis a complication of erythema nodosum leprosum. Am. J. Trop. Med. Hyg. 22:496-502, 1973.

33. Editorial - Arthritis in leprosy. Arch. intern. Med. 144:421, 1984.

34. Editorial - Lepromatous rheumatoid. Lancet 2:748-749, 1982.

35. EDMUNDSON, W.F.; WOLCOTT, R.R.; OLANSKY, S.; ROSS, H. Int. J. Leprosy, 22:440, 1954.

36. ESCOBAR-GUTIERREZ, A.; AMESCUA-CHAVARRIA, M.E.; PASTEN, S.; CASTRO, E.; FLORS, O.; RODRIGUES, O. Anticardiolipin antibodies in Mexican lepromatous leprosy patients. (Letter). Int. Lepr. other Mycobact. Dis. 58:723-724, 1990.

37. ESTRADA-PARRA, S.; ROJAS-ESPINOSA, O.; REYESGOMEZ, P. - Isolation of polisaccharids from M.leprae and M.lepraemurium and their reaction with sera from patients with leprosy. In: Transactions of the 9th International Leprosy Congress, London. Int. J .Leprosy 3:4, Pt2 abstract, Miscellaneous 231.

38. FRITZLER, M.J.; TAN. E.M. - Antinuclear Antibodies and the connective tissue diseases. In Cohen, A.S. Laboratory Diagnostic Procedures in the Rheumatic Diseases, $3^{\text {td }}$ ed., New York, Grune \& Stratton Inc., 1985, p.207-247.

39. FURUKAWA, F.; KASHIHARA, M.; IMAMURA, S.; OHSHIO, G.; HAMASHIMA,Y. Evaluation of anticardiolopin antibody and its cross-reactivity in sera of patients with lepromatous leprosy. Arch. Dermatol. Res 278:317$319,1986$.

40. GORMUS, B.J.; OSASHI, D.K.; OHKAWA, S.; WALSH, G.P.; MEYERS, W.M. - Serologic responses to Mycobacterium leprae specific phenolic glycolipid I antigen in sooth-mangabey monkeys with experimental leprosy. Int. J. Leprosy 56:537-545, 1988.

41. GUPTA, R.K.; MUKHERJIA, R.D.; GUPTA, S.; SAMUEL, K.C. - Electrophoretic pattern of serum proteins in leprosy. Int. J. Lepr. 144:453-455, 1976.

42. HARBOE,M. - Rheumatoid factors in leprosy and parasitic diseases. Scand. J. Rheumatol. (suppl) 75P:309-313, 1988.

43. HARTMANN, M.G. - Arthritis in infectious diseases. Verh Dtsch. Ges. Rheumatol. 3:59-66,1974.

44. HUNTER, S.W.; BRENNAN, P.J. Anovel phenolic glycolipid from Mycobacterium leprae possible involved in immunogenicity and pathogenicity. J. Bacteriol. 147:728$735,1981$.

45. IVESON, J.M.I.; MCDOUGALL, A.C.; LEATHEM, A.J.; HARRIS, H.J. - Lepromatous leprosy presenting with polyarthritis, myositis, and immune-complex glomerulonephritis. Brit. med. J. 3:619-621, 1975.

46. JHA, P.; BALAKRISHNAN, K.; TALWAR, G.P.; BHUTANI, L.K. - Status of humoral immune responses in leprosy. Int. J. Leprol. 39:14-19, 1971.

47. KARAT, A.B.A.; KARAT, S.; JOB, C.K; FURNESS, M.A. Acute exudative arthritis in leprosy, rheumatoid arthritis like syndrome in association with erythema nodosum leprosum. Brit. med. J. 3:770-772, 1967.

48. KUMAR, B.; GANGULY, N.K.; KAUR, S. - Complement profile in leprosy. Lepr. India 52:217-222, 1980.

49. LOUIE, J.S.; GLOVSKY, M. Complement determinations in the synovial fluid and serum of a patient with erythema nodosum leprosum. Int. J. Lepr. Mycobact. Dis. 43:242245, 1975.

50. MACKWORTH-YOUNG, C.G.; HARRIS, E.N.; STEERE, A.C.; et al.. - Anticardiolipin antibodies in Lyme Disease. Arthr. Rheum. 31:1052-1056, 1988.

51. MASALA, C.; AMENDALEA, M.A.; NICTI, M.; Riccarducci, R.; TARABINI, C.G.L.; TARABINI, C.G. Autoantibodies in leprosy. Int. J. Lepr. 47:171-175, 1978.

52. MATTHEWS, L.J.; TRAUTMAN, J.R - Clinical and serological profiles in leprosy. Lancet 2:915-918, 1965.

53. MEGHLAONI, A.; HERBAGE, D.; HUC, A.; MONIER, J.C. - Detection of anti-collagen type I and II antibodies by an immunoenzymatic technique (Elisa): results in rheumatoid arthritis, systemic lupus erthematosus and leprosy. Ann. immunol. 132:287-305, 1981.

54. MILLER, R.A.; WENER, M.H.; HARNISCH, J.P.; GILLILAND, B.C. The limited spectrum of antinuclear antibodies in leprosy. J. Rheum. 14:108-110, 1987.

55. MISSI, S.M.; ALMEIDA NETO, E.; SCHAF, S.; GONÇALVES, C.R.; RODRIGUES, C.J.; MARGARIDO, L.C. - Artrite específica em pacientes com lepra. Rev. Hosp. Clin. Fac. Med. Univ. S.Paulo 40:22-26, 1985.

56. MORAN, C.J.; RYDER, G.; TURK, J.L.; WATERS, M.F.R. - Evidence for circulating immune complexes in lepromatus leprosy. Lancet. 2:572-573, 1972.

57. NAVALKAR, R.G. - Immunologic analysis of M. leprae antigens and human sera by means of gel diffusion methods. In: Transactions of the 9th International leprosy Congress, London. Int. J. Leprosy 36:4 Pt2 abstract VII 97.

58. NEVES, R.A.; TEIXEIRA, L.A.N.; NEVES, R.G.; MANHÃES, L.F. Avaliação da imunidade celular na hanseníase indeterminada. Rev. bras. Malar. D. Trop. 34: 108-115, 1982.

59. NSIBAMBI, J.K. - Rheumatic manifestations in leprosy: a case report. E. Afr. med. J 60:805-808, 1983.

60. PELTIER, A.; CHRISTIAN, C.L. - The presence of the "Rheumatoid Factor" in sera form patients with syphilis. Arth. Rheum. II (1): 1-7, 1959.

61. PERNAMBUCO, J.C.A. - Artrite na reação hansênica. Hans. Int. 3:18-29, 1978.

62. PERNAMBUCO, J.C.A. - Hanseníase: um modelo de colagenose. In: VERTZMAN, L; DE PAOLA, D. Colagenoses. Rio de Janeiro, Epume, 1981. 
63. PERNAMBUCO, J.C.A.; OPROMOLLA. D.V.A.; TOLENTINO, M.M.; FLEURY, R.N. - Arthritis in lepromatous Hansen's disease. Int. J. Leprosy. 47 (suppl.2):353-354, 1979.

64. PETCHCLAI, B.; CHUTHANONDH, R.; RUNGROUNG, S.; RAMSOOTA, T. -Autoantibodies in leprosy among Thai patients. Lancet 1:1481-1482, 1973.

65. PETRI, V.; MENDES, E.V.; BEIGUELMAN, B. Histology of the Mitsuda Reaction of healtly adults with no known contacts with leprosy patients. Int. J. Leprosy 53:54-545, 1995.

66. PINTO, L.; BARBIERI, G. - La sieropositiva reumatoid nella lebbra. G. Malad. Infett. 16:456-462, 1964.

67. PLOTZ, C.M.A.; SINGER, J.M. - The latex fixation test. II results in rheumatoid arthritis. Am. J. Med. 21:893, 1956.

68. RABELLO, F.E. - Dissociated response to rheumatoid factor in lepromatous hanseniasis. [Letter]. J. Amer. med. Ass. 226:1228, 1973.

69. RAMOS, G.S.; BOTASSO, O.A.; MORINI, J.C.; SEGALEIRAS, A. - Evaluation of circulating immune complexes in leprosy. Rev. Argent. Microbiol. 20: 163-170, 1988.

70. RAO, T.D.; RAO, P.R. - Serum immune complexes in erthema nodosum leprosum reactions of leprosy. Indian J. Leprosy 68:189-195, 1988.

71. ROITT, I. - Essential immunology, Sixth Ed. London, Blackwell Scientific Publications Oxford, Chapter 6., p. 85 $100,1988$.

72. ROJAS-ESPINOSA, O.; MENDEZ-NAVARRETE, I.; ESTRADA-PARRA. S. - Presence of $\mathrm{Clq}$ reactive immune complexes in patients with leprosy. Clin. exp. Immunol. 12:215-222, 1972.

73. ROSS, H.; BUTLER, C.F.; LANKAITIS. R.B.C. - Reactive proteins in the sera of patients with leprosy. Int. J. Lepr. 27:129-133, 1959.

74. ROY, A.; AGARWAL, A.; RALHAN, R. Antiarabinogalactan $\mathrm{IgM} / \mathrm{IgG}$ ratio: a screening index for leprosy patients. Indian J. Lepr. 62:435-442, 1990.

75. SAAD, M.H.; MEDEIROS, M.A.; GALLO, M.E; GONTIJO, P.P.; FONSECA, L.S. - IgM immunoglobulins reactivy with the phenolic glycolipid -1 antigen from Mycobacterium leprace in sera of leprosy patients and their contacts. Mem. Inst. Osw. Cruz 85:191-194. 1990.

76. SAGHER, F.; SHESKIN, J.; ZLOTNIC K.A: et al.. Complement and immunologic determinants in leprosy and reaction. Int. J. Leprol. 39:541-553, 1971.

77. SAHA, K.; CHAKRABARTY, A.K. - Serum complement proliles in human leprosy and its comparison with immune complex diases. Int. J. Leprol. 45: 327-337, 1977.

78. SAITZ, E.W.; DIERKS, R.E.; SHEPARD, C.C. Int. J. Leprosol. 36:400, 1968.

79. SANTIAGO, M.B.; COSSERMELLI, W.; TUMA, M.F.; PINTO M.N.; OLIVEIRA. R.M. - Anticardiolipin antibodies in patients with infectious diasease. Clin. Rheum. 8:23-28, 1989.

80. SEHGAL, V.N. - Eletrophoretic patterns of serum proteins in leprosy Int. J. lepr. 36: 413-416, 1968.

81. SEHGAL, V.N - SHARMA, V.K. - Comprehensive evaluation of complement components in the course of the type I (lepra) and type II (ENL) reactions Int. J. Dermatol. 28:32-35, 1989.

82. SHARMA., V.K.; SAHA, K.; SEHGAL, V.N. - Serum immunologlobulins and autoantibodies during and after erythema nodosum leprosum. Int. J. leprosy 50(2): 159-163, 1982.

83. SINGER, J.M.; PERALTA, F.M.; LYONS, H.D.; PLOTZ, C.M. - Presence of "Serologically active macroglobus" in sera of some patients with active pulmonary tuberculosis. Arth. Rheum. 4:124, 1961.

84. SULCEBE. G.; NAKUCI, M. - Ati-phenolic glycolipid 1 IgM antibodies in leprosy patients and in their household contacts. Leprosy Rev. 61:341-346, 1990.

85. VALENTIJA, R.M.; FABER, W.R.; LAI, A.; FAT, R.F. Immune complexes in leprosy patients from an endemic and nonendemic areas. Clin. Immunol. Immunopath. 22:194$202,1982$.

86. WEMAMBU, S.N.C.; TURK, J.L.; WATERS, M.F.R.; REES, R.J.W. - Erythema nodosum leprosum: a clinical manifestation of the Arthus phenomenon. Lancet 2:933-935, 1969. 